\title{
Ecological interpretations of the leaf anatomy of amphibious species of Aeschynomene L. (Leguminosae - Papilionoideae)
}

\author{
Leme, FM.* and Scremin-Dias, E. \\ Laboratory of Plant Anatomy, Laboratory of Botany, CCBS, Federal University of Mato Grosso do Sul - UFMS, \\ Av. Costa e Silva, s/n, CP 549, CEP 79070-900, Campo Grande, MS, Brazil \\ *e-mail: flaviabotanica@gmail.com
}

Received: August 9, 2012 - Accepted: December 13, 2012 - Distributed: February 28, 2014

(With 6 figures)

\begin{abstract}
We present the leaf anatomy of seven amphibious species of Aeschynomene L. (Papilionoideae, Leguminosae), interpreting their structures and ecological functions, and also, providing information on which their taxonomy can be based, especially of morphologically similar species. We evaluated Aeschynomene americana, A. ciliata, A. evenia, A. denticulata, A. fluminensis, $A$. rudis and A. sensitiva. The anatomy corroborates the separation of the series Americanae, Fluminenses, Indicae and Sensitivae, with the shape of the petiole, types of trichomes and quantity of vascular units in the petiole as main characteristics to delimit the species. The petiole shape varies from cylindric in $A$. americana, A. sensitiva and A. fluminensis, to triangular in A. evenia and quadrangular in A. rudis, A. denticulata and A. ciliata. We observed four types of trichomes: hydathode trichome, long conic trichome, short conic trichome and bulb-based trichome. The hydathode trichome was the most common, except for A. americana and A. fluminensis. Species with higher affinity with water share similar adaptive characteristics, including hydathode trichomes described for the first time for the genus. This article adds unseen descriptions for the genus and on the adaptation factors of the amphibious species.
\end{abstract}

Keywords: macrophytes, Fabaceae, hydathode trichome.

\section{Interpretações ecológicas da anatomia foliar de espécies anfíbias de Aeschynomene L. (Leguminosae - Papilionoideae)}

\begin{abstract}
Resumo
Neste trabalho é apresentada a anatomia foliar de sete espécies anfíbias de Aeschynomene L., interpretando estruturas e suas funções ecológicas e fornecendo informações que subsidiam sua taxonomia, principalmente de espécies semelhantes morfologicamente. Foram avaliadas Aeschynomene americana, A. ciliata, A. evenia, A. denticulata, A. fluminensis, A. rudis e A. sensitiva, pertencentes ao grupo Papilionoideae - Leguminosae. A anatomia corrobora a separação das séries Americanae, Fluminenses, Indicae e Sensitivae, sendo o formato do pecíolo, tipos dos tricomas e quantidade de unidades vasculares no pecíolo as principais características para delimitação das espécies de Aeschynomene. O formato do pecíolo variou de cilíndrico para A. americana, A. sensitiva e A. fluminensis, triangular para A. evenia e quadrangular para $A$. rudis, $A$. denticulata e $A$. ciliata. Foram observados quatro tipos de tricomas, são eles: tricoma-hidatódio, tricoma cônico longo, tricoma de base bulbosa e cônico curto. O tricoma-hidatódio foi o mais comum, ausente somente em A. americana e A. fluminensis. Espécies com maior afinidade pela água compartilham características adaptativas similares, incluindo tricoma-hidatódio descrito pela primeira vez para o gênero. Este trabalho acrescenta descrições inéditas para o gênero e sobre fatores adaptativos das espécies anfíbias.
\end{abstract}

Palavras-chave: macrófitas, Fabaceae, tricoma-hidatódio.

\section{Introduction}

The genus Aeschynomene L., of neo-tropical distribution, has approximately 160 species (Fernandes, 1996). It has economic and ecologic relevance for use as forage, ornamental, medicinal, bee plant, nitrogen fixation or weed (Lima et al., 2006; Pott and Pott, 1994).

Some species of Aeschynomene have affinity to water, such as the Aeschynomeneae section, which comprises five series: Americanae, Fluminenses, Indicae, Montevidenses and Sensitivae. Those are present in the state of Mato Grosso do Sul, Brazil (Lima et al., 2006). Some of them occur preferably on borders of lakes, ponds, rivers and locations of constant flooding in Pantanal wetlands, Central-West of Brazil (Lima et al., 2006; Pott and Pott, 2000). 
The amphibious species remain in aquatic habitats in periods of high waters and grow on flood free soils during dry periods (Sculthorpe, 1967). So, the plants concentrate in a gradient of humidity on the littoral zone of water bodies (Scremin-Dias, 1999), being subject to the seasonal variation of water level, reflecting in morphological, structural, anatomic and physiological alterations of vegetative organs. These characteristics were responsible for the success in colonising these still little-known environments (ScreminDias, 1999; Scremin-Dias et al., 2011), especially regarding adaptive peculiarities (Scremin-Dias, 2009).

Some species of Aeschynomene have morphological similarities, being possible to distinguish them only by their reproductive structures (Lima et al., 2006), e.g. A. evenia C. Wright, A. denticulata Rudd and A. rudis Benth. (series Indicae), which need taxonomic revision (Lima et al., 2006). These species have plasticity in the development of vegetative organs, such as stem thickening, and presence of adventitious roots and lenticels. Morphological changes respond to seasonal flood of the Pantanal (Scremin-Dias et al., 2011), reflecting in difficult botanical identification. According to Alho (2011), the Pantanal needs ecological studies, to understand the adaptations to this ecosystem, aiming at its conservation.

For some species of Aeschynomene the types of trichomes are essential in species identification (Lima et al., 2006), and studies made by Zoric et al. (2012) with species of Fabaceae reinforce the importance of trichomes and crystals in the identification of taxa, besides other anatomic characters that aid delimitation of sections of the genus.

Some types of trichomes are more common in one taxon than in another, therefore are of diagnostic value, a consistent pattern of description that may help a taxonomist in comparisons (Metcalfe and Chalk, 1979). However, the presence of hydathode trichomes may also reflect the plant habitat, as it is not surprising to find hydathodes in aquatic or wetland plants (Metcalfe and Chalk, 1979). Hydathodes are characterised by the presence of aquifer pores which resemble stomata (Fahn 1979; Lersten and Curtis, 1985), presence of epithem, elements of conductance exclusively xylematic and open bundle sheath (Fahn, 1979) are essential in eliminating excess of water. Beside hydathodes, the hydathode trichomes also secret a large quantity of water, as in Monarda fistulosa L. (Heinrich, 1973) and Cicer arietinum L. (Metcalfe and Chalk, 1979). Despite hydathode trichomes not having been described in detail by Metcalfe and Chalk (1979), these authors mention their morphological appearance of glands, and that in Machaerium oblongifolium (Fabaceae) these structures are like long and conic multicelular trichomes, which exsudate water through the lateral walls of terminal cells.

The analysis in plant anatomy indicates taxonomic and ecologic applications (Solereder, 1908; Metcalfe and Chalk, 1979). The studies made over the last decade have shown that the anatomy of the root, stalk and specially leaves, are consistent for the infra-generic or genus separation (Jesus Junior et al., 2012; Gomes et al., 2009; Lusa and Bona, 2009), especially for Papilionoideae (Teixeira and
Gabrielli, 2006; Sartori and Tozzi, 2002; Crow et al., 1997). The anatomy is also applied in the interpretation of the phenotype plasticity in amphibious species located in lagoons and wetlands of Pantanal (Scremin-Dias, 1999; Scremin-Dias et al., 2011).

The application of anatomy in taxonomic studies must be made cautiously to establish which characters in fact have taxonomic value, or are only mere alterations due to environmental changes (Metcalfe and Chalk, 1950). In this study, using the analysis of leaf anatomy of amphibious species of Aeschynomene, we highlight the adaptive anatomic characters and point out those important for the taxonomy of species with hard delimitations, assessing if the anatomy of the species in the genus corroborates the definition of the evaluated series.

\section{Material and Methods}

The species Aeschynomene americana L., A. fluminensis Vell., A. sensitiva Sw., A. ciliata Vogel, A. evenia C. Wright, $A$. denticulata Rudd and $A$. rudis Benth., widely distributed in floodable areas of the Pantanal, belong respectively to four series: Americanae, Fluminenses, Sensitivae and Indicae, the last one comprising four species.

Samples of $A$. rudis, A. americana, A. fluminensis, A. ciliata and A.sensitiva were collected in wet areas of the Pantanal, Central-West of Brasil, and A. rudis was collected in the field and also obtained from herborised material, while $A$. denticulata and $A$. evenia were only taken from herborised material. Specimens are kept in the Herbarium CGMS, Campo Grande-UFMS: A. rudis (V.J. Pott et al. 4559; V.J. Pott \& A. Pott 6056; F.M. Leme 06; F.M. Leme 09); A. americana (F.M. Leme 01), A. fluminensis (E. Scremin-Dias CGMS 25853; F.M. Leme 03; F.M. Leme 04), A. ciliata (F.M. Leme \& V. Pott 08); A. sensitiva (F.M. Leme 02; F.M. Leme 05; F.M. Leme 07; E. Scremin-Dias CGMS 25855); A. denticulata (V.J. Pott \& A. Pott 4248; V.J. Pott \& A. Pott 6054; J.M.F. Valls et al. 9460) and A. evenia (J.M.F. Valls et al. 8681; L.C.O. Lima 85).

The samples were fixed in FAA 50\% for 48 hours, later washed in running water and dehydrated in ethylic series until alcohol 70\% for storage (Johansen, 1940). Herborised material of $A$. denticulata, A. evenia and $A$. rudis was rehydrated in glycerin water at $10 \%$ for 24 hours, in an oven at $60{ }^{\circ} \mathrm{C}$, and stored in alcohol $70 \%$ for posterior analysis.

Free hand sections were made in the median region of leaflets obtained in the mid-section of the leaf, in three specimens of the same population, or when possible, from different populations - clarified in hypochlorite $50 \%$ and stained in astra blue and aqueous safranin at $1 \%$, according to the usual techniques compiled by Kraus and Arduin (1997). The analysis of the epidermal cells was made using paradermal sections, in semi-permanent slides mounted in glycerin $50 \%$, sealed with colourless enamel. To produce the permanent slides, the material was embedded in historesin, prepared according to the manufacturer's instructions, and stained with toludine 
blue. The histochemical tests for mucilage and phenolic compounds were made according to Langeron (1949) and Johansen (1940).

The electromicrographies of epicuticular wax and trichomes were obtained using a Scanning Electronic Microscope (SEM) JEOL JSM-6380LV, and the documentation in Photonic Leica Microscope DMLB, attached to an image capture system. Diagrams were also made using a camera lucida attached to an Olympus optical microscope.
The differential anatomical characters of the species enabled the production of a table of presence and absence of characters to observe similarity of species.

\section{Results}

The transversal section of the petiole shows distinct shapes for the seven evaluated species (Figure 1A-G). The shape of petiole varied from cylindric in $A$. sensitiva, A. fluminensis and A. americana (Figure $1 \mathrm{C}, \mathrm{F}$ and $\mathrm{G}$ ),
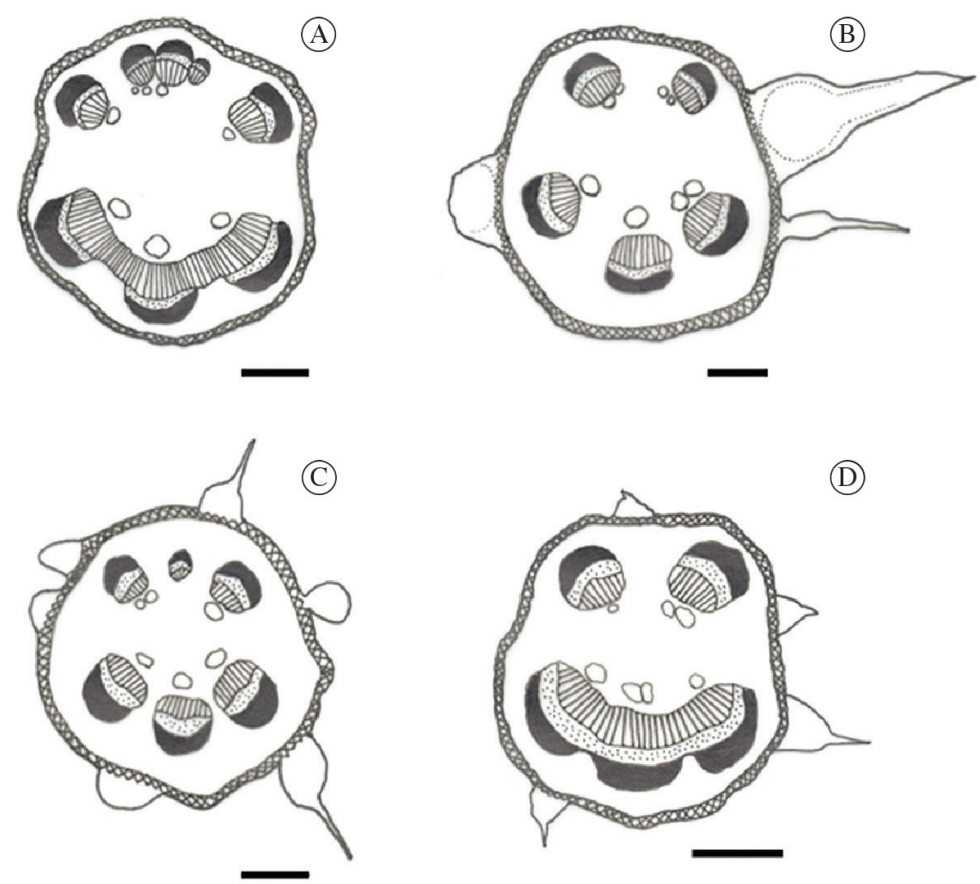

(D)
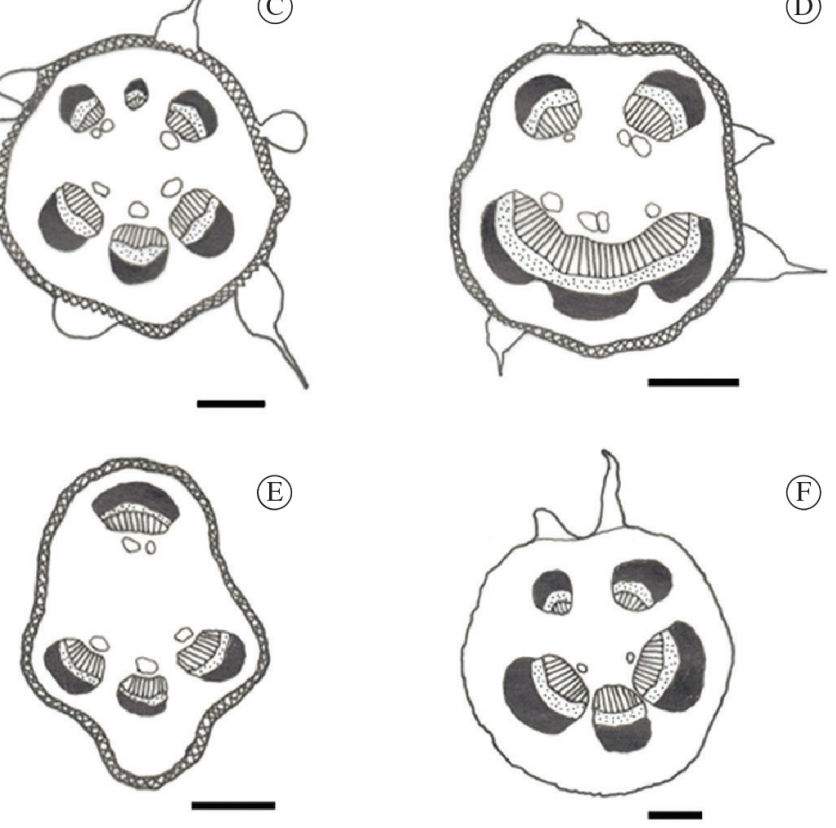

(F)
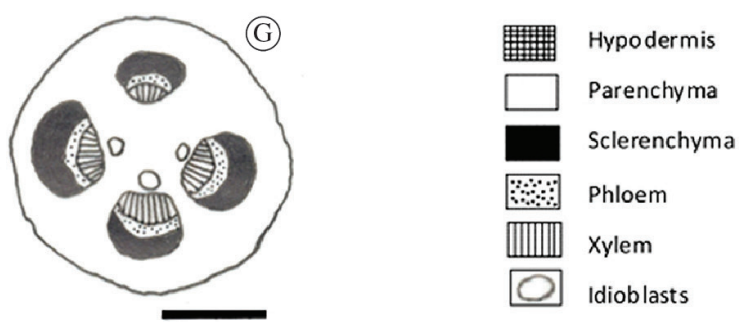

Figure 1. A-G. Diagram of the transveral section of the petioles. Aeschynomene rudis Benth. (A); A. ciliata Vogel (B); A. sensitiva Sw. (C); A. denticulata Rudd (D); A. evenia C. Wright (E); A. fluminensis Vell. (F); A. americana L. (G). Scale $200 \mu \mathrm{m}$. 
to triangular in $A$. evenia (Figure 1E) and quadrangular in $A$. rudis, $A$. ciliata and $A$. denticulata (Figure 1A, B and D). On $A$. sensitiva, $A$. ciliata and $A$. denticulata we observed various evident trichomes around the petiole (Figure 1B, C and D).

Multicellular trichomes are present on the petiole of all evaluated species, classified in four types according to their shape and structure: hydathode trichome (Figure 2A), long cone-shaped trichome (Figure 2B), bulb-like base trichome (Figure 2C), and short cone-shaped trichome (Figure 2D), with distinct distribution among the species, and easily differentiated under SEM (Figure 2E-G).

Hydathode trichome, present on the petiole and on the margin of the leaflets of $A$. rudis, $A$. denticulata, A. evenia, $A$. ciliata and $A$. sensitiva, varies from $0.05 \mathrm{~mm}$ to $1.6 \mathrm{~mm}$. However, only in $A$. ciliata this trichome achieves $1.0 \mathrm{~mm}$ to $1.6 \mathrm{~mm}$. It is characterised by having an accentuated robust base forming an epithem, with parenchymatic cells

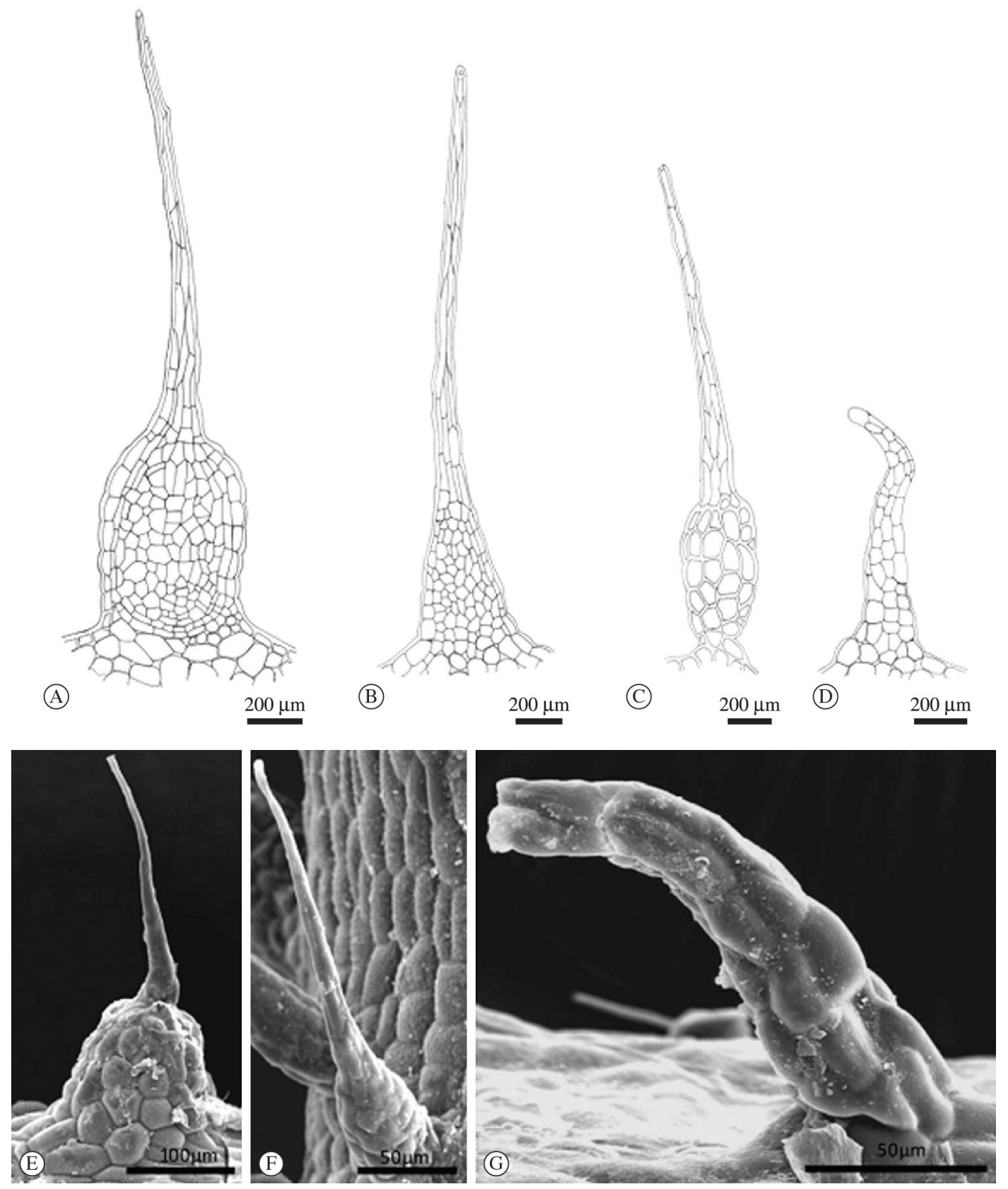

Figure 2. A-G. Trichomes of Aeschynomene seen under photonic microscopy (A-D) and SEM (E-G). Aeschynomene ciliata Vogel (A); A. americana L. (B and F); A. ciliata Vogel (C); A. fluminensis Vell. (D and G); A. denticulata Rudd (E). Hydathode trichome (A and E); Long cone-shaped trichome (B and F); Bulb-shaped base trichome (C); Short cone-shaped trichome (D and $G)$. 

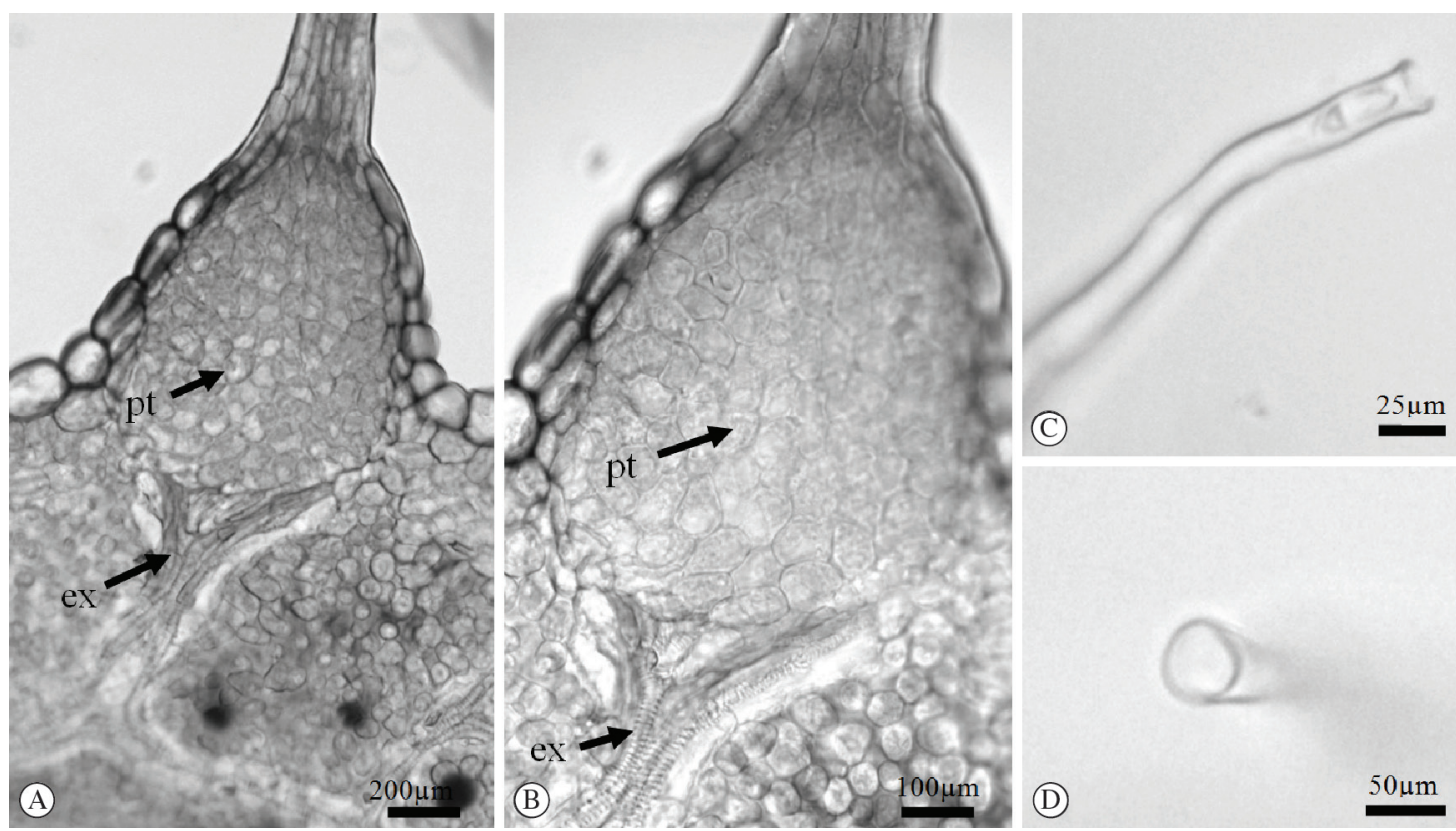

Figure 3. A-D. Hydathode trichome of Aeschynomene ciliata Vogel, in paradermic section of the leaflet. Base of trichome showing vascular bundles (ex) and the epithem (pt) (A); Tops of xylem elements (ex) close to the epithem (pt), and this formed by thin wall cells (B); Top of trichome (C); Secretor pore (D).

of thin wall (Figure $3 \mathrm{~A}$ and $\mathrm{B}$ ). Close to the epithem occur terminations of xylem elements (Figure 3A). Upon the basis sharper long stalk is projected, with reduced number of elongated cells close to the apex, delimiting the pore secretor of water on its extremity (Figure $3 \mathrm{C}$ and $\mathrm{D}$ ). The process of water secretion was observed during field collections, occurring more intensely in partially submerged species, mainly in A. sensitiva and A. ciliata.

Cone-shaped trichomes were seen exclusively in A. americana and A. fluminensis differing in format between these species, being long and distributed uniformly in A. americana (Figure 2B and $\mathrm{F}$ ), and short and concentrated on the adaxial side in A. fluminensis (Figure 2D and $\mathrm{G})$. While the trichome of the bulb-like base present in A. americana (Figure 2C) is long and rare, in A. ciliata it is short and rounded at the base.

The petiole is coated with an uniseriate epidermis (Figure 4A) slightly papilosous (Figure 4B), with internal and external periclinal walls remarkably thick in all species (Figure 4C). Right below the epidermis, the hypodermis (Figure $4 \mathrm{~A}$ and $\mathrm{B}$ ) occurs on the petiole of five evaluated species, except in A. americana and A. fluminensis (Figure 4C). In these species, the chlorophyllian parenchyma is located right under the epidermis, with the presence of phenolic compounds in the cortex cells (Figure 4C and D). Vascular bundles of the collateral type with sclerenchyma caps externally to the phloem (Figure 4A) are coated by a sheath of parenchymatic bands containing rhomboid or styloid crystals (Figure 4E and F). Five vascular units are distributed in the petiole of A. ciliata (Figure 1B), A. denticulata (Figure 1D) and A. fuminensis (Figure 1F), six units in A. sensitiva (Figure 1C) and seven or more in $A$. rudis (Figure 1A), and only four vascular units in A. evenia and A. americana (Figure $1 \mathrm{E}$ and $\mathrm{G}$ ). Elongated secretion idioblasts with a wide lumen containing phenolic compounds are associated to each vascular unit, next to the center of the petiole (Figure 1A-G and Figure 4D), of all analyzed species.

The leaflet blade is coated by overlapped epidermal cells (Figure 5A-I), with sinuous outline (Figure 5A-B) in the anticlinal walls of the internervural cells, for most part of the evaluated species. Slightly straight walls predominate in A. fluminensis (Figure 5C). The epidermal cells that coat the midrib have straight and rectangular-shaped anticlinal walls in all evaluated species. The stomata are predominantly anisocytic (Figure 5B), and also anomocytic and paracytic, the last one present exclusively in A. americana and A. fluminensis (Figure 5A and C). Scanning Electronic microscope analysis detected a smooth epidermal surface, with no wax ornamentations in A. denticulata (Figure 5D), and epicuticular wax present in most species (Figure 5E-I). Wax ornamentations with little variation in the type of deposition seen in A. fluminensis, with wax deposited in scale covering part of the cell surface, and granules on the stomata cells and among common cells of the epidermis (Figure 5E), deposition of granulose wax in great quantity including the stomatic cells in $A$. rudis and A. ciliata (Figure 5F-G). For $A$. sensitiva and $A$. evenia the wax depositions occur on the external periclinal walls and among the cells the wax appears in the shape of small granules (Figure 5H-I). 

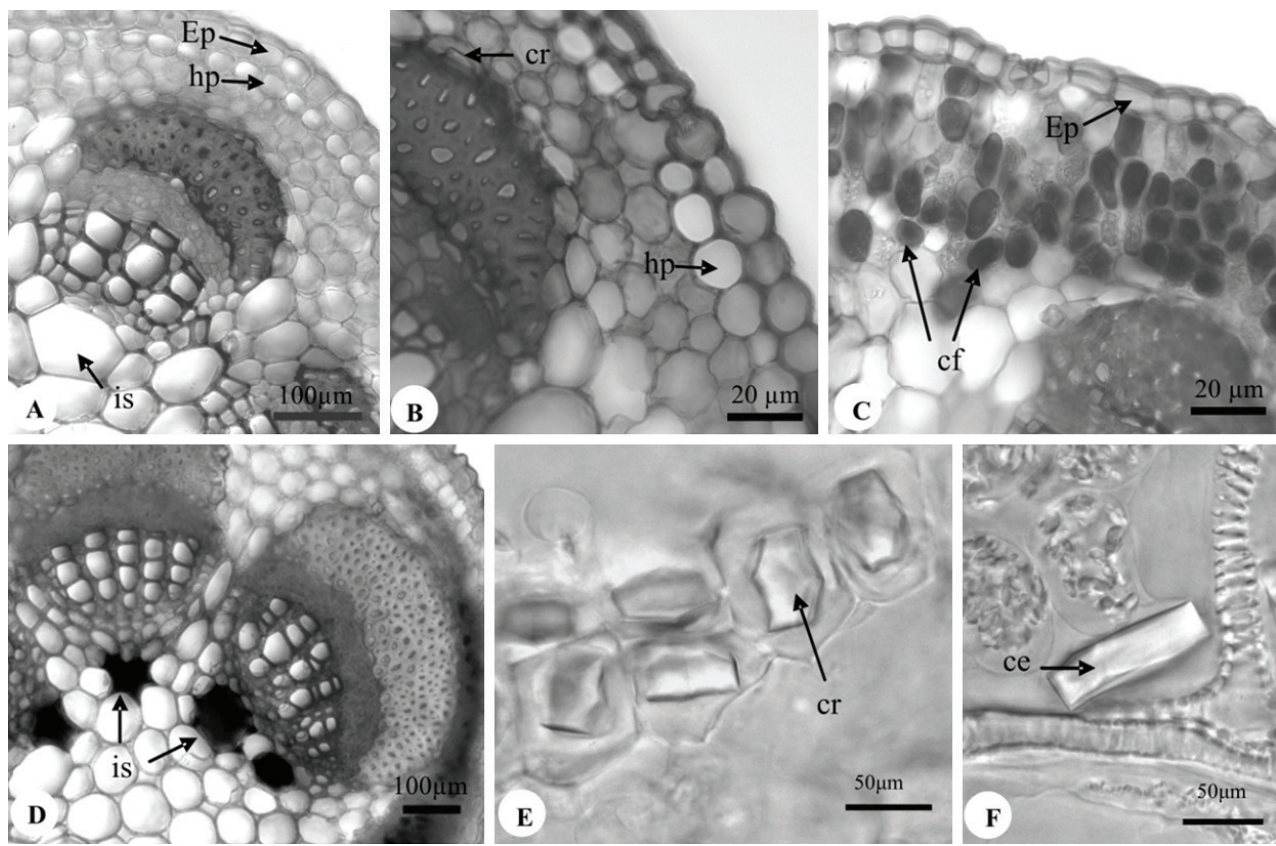

Figure 4. A-F. Tranversal sections in petioles of Aeschynomene showing the hypodermis (subcutaneous tissue), crystals and phenolic compounds. Aeschynomene rudis Benth. (A and B); A. americana L. (C); A. fluminensis Vell. (D); A. americana L. (E) and A. evenia C. Wright (F). Papillary epidermis (Ep), hypodermis (hp) and secreting idioblast (is) (A, B, C and D). Rhomboidal crystals (cr) in the sheath of the vascular bundle (B and E). Phenolic compounds (cf) the cells of the cortex (C). Styloid crystals (ce) (F).
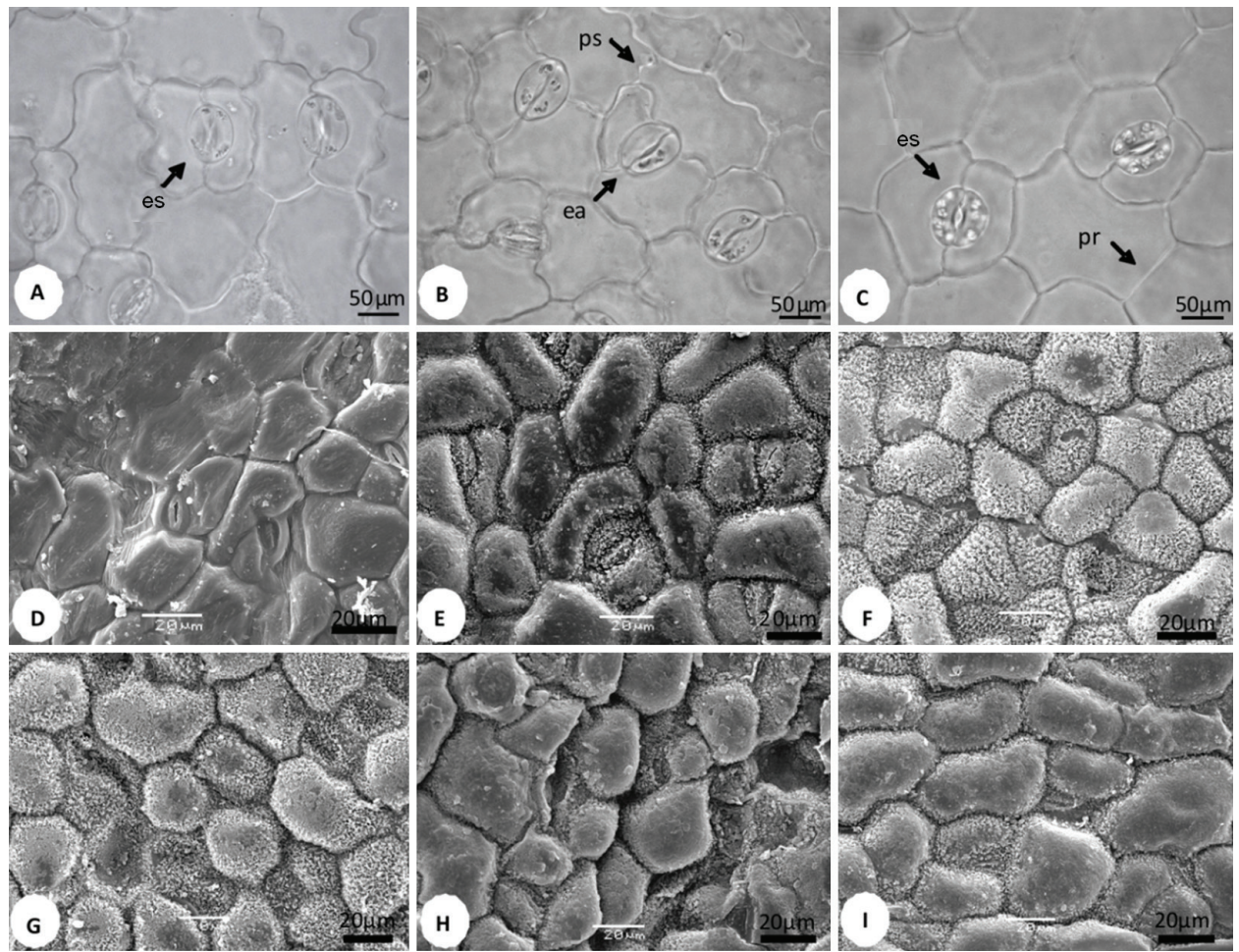

Figure 5. A-I. Epidermis of the leaflet limbus of Aeschynomene frontal view in photonic microscopy (A-C), and SEM of the abaxial side of the leaflet (D-I). A. americana L. (A); A. ciliata Vogel (B and G), A. fluminensis Vell (C); A. denticulata Rudd (D); A. fluminensis Vell (E); A. rudis Benth. (F); A. sensitiva Sw. (H) and A. evenia C. Wright (I). Paracytic stomata (es) (A and C). Ansiocytic stomata (ea) (B). Ordinary cells of the epidermis with sinuous outline walls (ps) (B) and slightly straight anticlinal wall (pr) (C). 
The hydathode trichome found on the margin of the leaflet is similar to the one seen on the petiole in different species. In A. americana the bulb-shaped base trichomes (Figure 2C) and long cone-shaped ones (Figure 2B-F) are seen on the petiole and only on the leaflet apex.

The leaflet is anfistomatic and bifacial in all species (Figure 6A-F), with a palisade parenchyma varying from two to five layers; A. fluminensis presents four to five layers of this tissue (Figure 6C), and the other species show two or three layers (Figure 6A and E). The spongy parenchyma has four layers in A. sensitiva, and in the other species predominate two to three layers.

The secreting cells, idioblasts common to all species, are disposed among the cells of the palisade parenchyma (Figure 6B and E), have a long and wide shape, contain mucilage and prominent size that may reach the entire extension of this tissue (Figure 6B). Idioblasts with phenolic compounds are distributed in the parenchyma cells in the
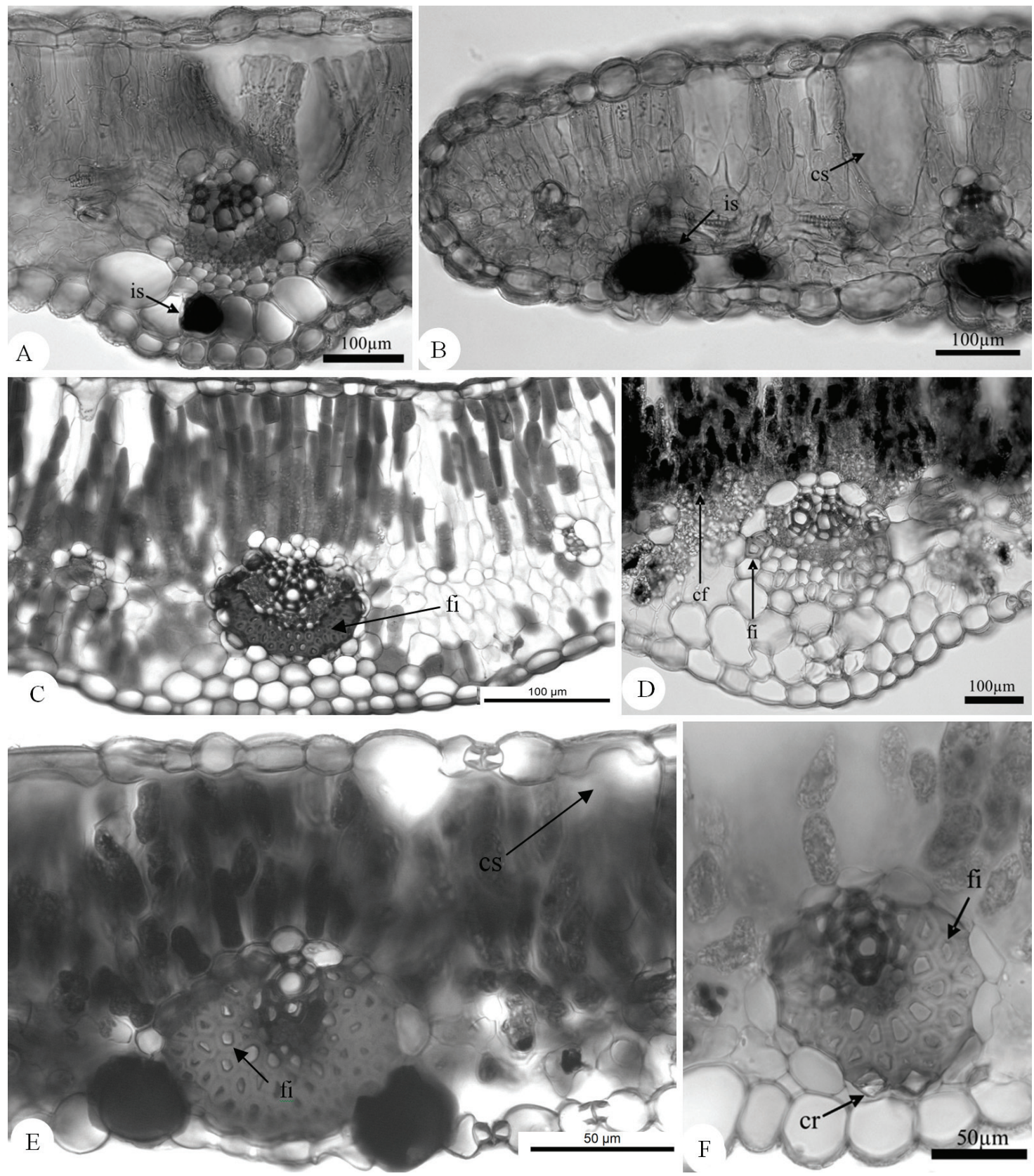

Figure 6. A-D. Transversal sections of the mesophyll of Aeschynomene. A. sensitiva Sw. (A and B); A. fluminensis Vell. (C and D) and A. americana L. (E and F). Secreting idioblasts (is) in the midrib (A). Secreting cells in the mesophyll and secreting idioblasts in the margin of the leaflet (B). Fibres (fi) in the midrib and cells of the parenchyma with phenolic compounds (cf) (C and D). Fibres (fi) in the nervure of the margin and rhomboid crystals (cr) (E and F). 
cortex and mesophyll in A. americana and A. fluminensis (Figure 6C, D and E).

The species $A$. evenia, $A$. denticulata, $A$. rudis, $A$. sensitiva and $A$. ciliata have secreting idioblasts with phenolic compounds in the abaxial side of the midrib (Figure 6A), visible in A. sensitiva associated to the vascular bundle of the margin (Figure 6B). For A. ciliata these idioblasts occur in the adaxial side, next to the xylem, similar to those found in the vascular units of the petiole.

The leaflet's midrib in all species is small, it is coated by a parenchymatic sheath with crystals (Figure 6F) of the styloid type (Figure 4F) in A. evenia, A. denticulata, A. ciliata, A. rudis, A. sensitiva and A. fluminensis; and rhomboidal in A. americana and A. fluminensis (Figure 4E). Sclerenchyma caps are present in A. americana and A. fluminensis, distributed externally to the conductor tissues of the midrib (Figure 6C-F).

Comparative analysis of anatomical characteristics allowed to group species which share similar structures. Characters such as presence and absence of types of trichomes, hypodermis, phenolic compounds, idioblasts, crystals and types of stomata, were consistent to support distinction of the analysed series (Table 1). Furthermore, the shape of petiole, number of vascular bundles and presence and absence of conic and bulb-based trichome were essential in separation of species of the series Indicae, which comprises the species of difficult taxonomical delimitation (Table 1). Such and other anatomical characteristics useful in separation of the seven species of Aeschynomene are shown in Table 1.

\section{Discussion}

The structure of the petiole is a remarkable character in differentiation of Aeschynomene species, since it has a considerable taxonomic importance in many genera, once it is less affected by environmental changes (Metcalfe and Chalk, 1950), which is corroborated by our data. The number of the vascular bundles in the petioles was one of the main anatomical features, supported separation of those species morphologically very similar and hard to determine, such as $A$. denticulata, A. evenia and $A$. rudis.

Besides, bulb-shaped trichomes were consistent for the separation of $A$. americana and $A$. ciliata from the other studied species. These garments described in the subtribe Aeschynomeneae by Polhill and Raven (1978), were reported as useful to delimit the genera of the subtribe Cajaninae, within the Phaseoleae tribe (Lackey, 1978), and to separate other species of Leguminosae, for example of the genus Indigofera L. (Marquiafável et al., 2009).

Hydathode trichomes described with five of the seven evaluated species, is the first report for the genus. The term hydathode trichome, used by Heinrich (1973) for glandular trichomes that secrete salt solutions, had already been reported for Cicer arietinum L. and Machaerium oblongifolium Vog. (Metcalfe and Chalk, 1979). However, we did not find detailed description of the structure of hydathode trichomes, only Metcalfe and Chalk (1979) described it for
M. oblongifolium, long and conic multicelular hydathode trichomes. Although this term had not been utilised for the Section Aeschynomeneae, Polhill and Raven (1978) and Lima et al. (2006) reported glandular trichomes for this section. Also, the trichome has characteristics similar to hydathodes and to trichomes described for M. oblongifolium.

The hydathode trichomes showed relation with the species with higher affinity to flooding, in which part of their stalks remain submerged most of the seasonal cycle. For Dickison (1975), some types of trichomes came from independent lineages, and could have no importance in taxonomic and phylogenetic studies. In our study, the hydathode trichome was exclusive in the species of the evaluated series Indicae and Sensitivae, in which the species are distributed in wetter areas (Lima et al., 2006).

For emerging amphibious plants, the elimination of excess water by hydathodes optimises the uptake of nutrients (Sculthorpe, 1967) that are diluted in the aquatic environment (Scremin-Dias, 2009). Among several roles played by glandular trichomes, such as defense, pollination, elimination of water and others, some yet unknown (Ascensão et al., 1999), the elimination of the excess of water from tissues is the main function interpreted for the hydathode trichomes of the evaluated species.

Idioblasts secreting tannin distributed in the center of the petiole of Aeschynomene have already been described by Metcalfe and Chalk (1950), besides the occurrence of tannins, proteins, mucilage among other compounds. For those authors the presence of secreting idioblasts around the bundles can happen in a number of genera of Papilionoideae, so we corroborated the distribution of these idioblasts around the midrib of the leaflets of $A$. evenia, A. denticulata, A. ciliata, $A$. rudis and $A$. sensitiva. The distribution of secreting idioblasts was consistent to separate A. sensitive, the only species with idioblasts in the margin of the leaflet, from the other evaluated species, being absent in the midrib of $A$. americana and A. fluminensis, corroborating Dickison (1975) as for the taxonomic value of these structures for several botanical groups.

The secreting cells distributed in the mesophyll and not associated to the vascular bundles, have already been reported for Machaerium longifolium Benth. (Solereder, 1908), genus that shares with Aeschynomene the subclade Dalbergia. According to Lavin et al. (2001), some species of Aeschynomene are intimately related to Machaerium, since the genus Aeschynomene is not monophyletic (Ribeiro et al., 2007).

For $A$. americana and $A$. fluminensis that occupy areas of shallow waters or flood free, the large quantity of phenolic compounds in the cortex and mesophyll could be reflecting the ecologic strategies in detriment to the taxonomic relations (Wink, 2003). We believe that the presence of phenolic compounds in Aeschynomene can be related to the plant defense system, due to the species being in shallow waters, having tender leaflet tissues, which can favour herbivory. Some authors relate its presence with the protection against desiccation (Esau, 1985; Fahn, 1979). Therefore, we must consider that the evaluated species 


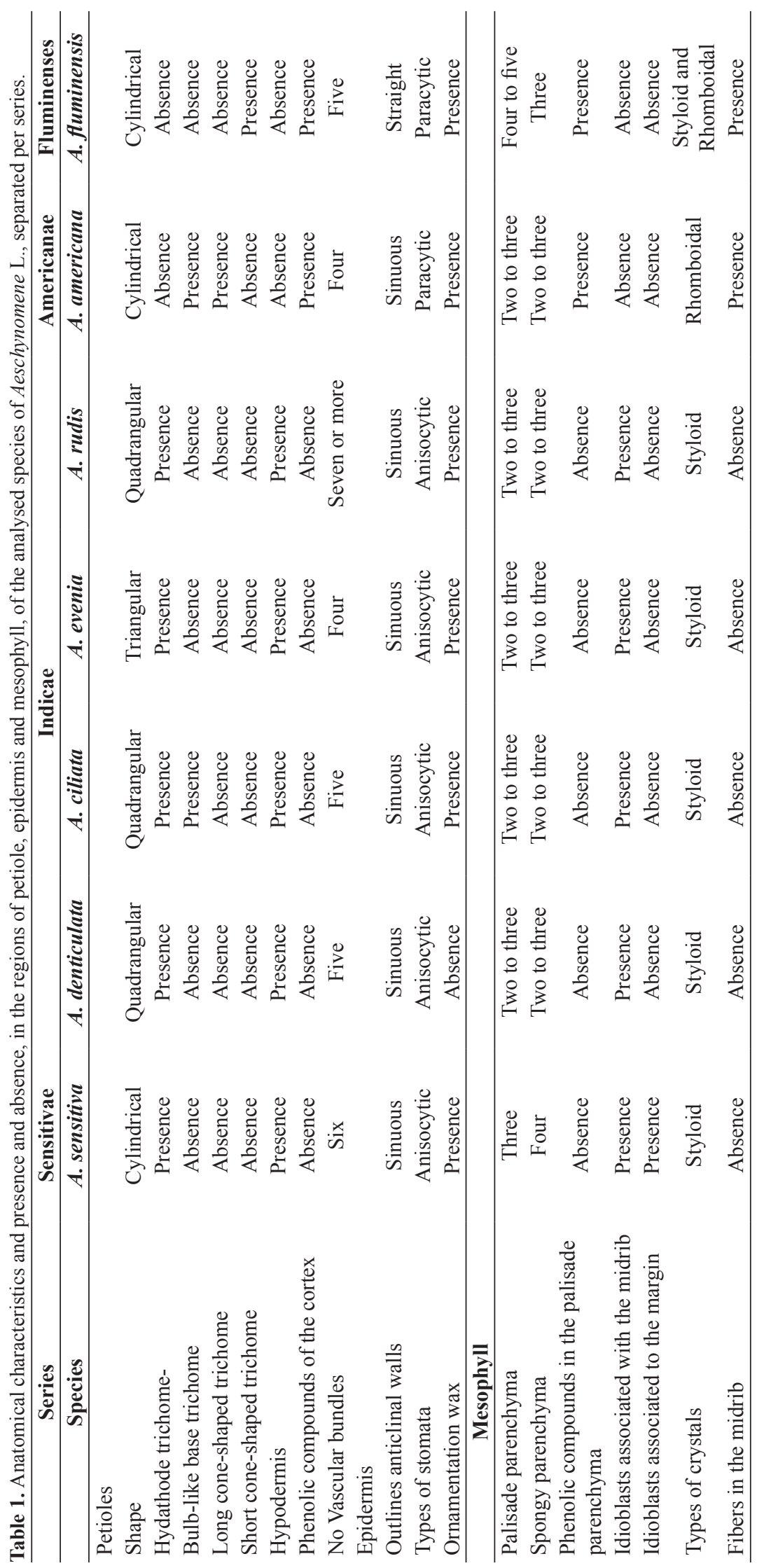


are amphibious, placing themselves part of the year in soil free from flooding, submitting the plant to the stress of lack of water.

The pattern of the sinuous outline of the anticlinal wall in epidermal cells obtained for the evaluated species - except A. fluminensis, is not a consistent character to separate the species, despite Metcalfe and Chalk (1979) confirm that this characteristic can be used for taxa in generic or specific level. However, sinuous anticlinal walls can reflect ecological patterns, being mentioned for most aquatic species or wet environments (Metcalfe and Chalk, 1979; Solereder, 1908), and straight anticlinal walls for xerophytes (Fahn and Cutler, 1992). Despite A. fluminensis being a palustrine species, it is widely distributed in the littoral zone of lakes, shallow waters, differing from the other evaluated species for presenting slightly sinuous anticlinal walls.

The protective barrier against water loss by excessive transpiration is the main function cited for the epicuticular wax (Fahn and Cutler, 1992). However, the evaluated species of Aeschynomene are amphibious, with no water restriction in the environment, except during the dry period in the Pantanal. The presence of wax in these species can be related to the protection against actions of pathogens or solar radiation (Silva et al., 2005). The ornamentation of epicuticular waxes showed taxonomic value for $A$. denticulata, A. evenia and A. rudis, species of hard determination, corroborating Wilkinson (1979) and Alquini et al. (2003) regarding the diagnostic character of the shape of epicuticular wax deposit in the leaflet surface for some taxa.

Crystals in the leaflet blade have not been recorded for Aeschynomene, being described for Fabaceae (Metcalfe and Chalk, 1985; Heneidak and Shaheen, 2007) and for the subgroup Papilionoideae (Crow et al., 1997). The rhomboid crystals, noticeable characteristic of the series Americanae, occur only in A. americana, and corroborates the taxonomic value of these structures (Dickison, 1975). The presence of crystals can be associated to the need for organ support (Solereder, 1908), especially in species in which fibres are absent, what commonly occurs in species distributed in floodable areas

The shape of the petiole, epidermal appendages, secreting idioblasts, fibres in the mesophyll and the quantity of vascular units are diagnostic characteristics of vegetative organs, essential in the separation of the species of Aeschynomene, also corroborating their series. However, other characteristics like the structure of the mesophyll, stomata, outline of epidermal cells, crystals and phenolic compounds, characterize the affinity of occurrence in the evaluated species, corroborating Zoric et al. (2012). Therefore, especially in the absence of fibres in the mesophyll and presence of hydathode trichome is shared by species that are distributed in areas with more intense flooding, seen in A. denticulata, A. evenia, A. rudis, $A$. sensitiva and $A$. ciliata.
Acknowledgements - To CAPES for the scholarship to F.M. Leme; to MSc. Vali Joana Pott for lending the herbarium material; to Dr. Laura Cristina P. Lima for botanical identification; and to Prof. Dr. Arnildo Pott for revision of English.

\section{References}

ALHO, CJR., 2011. Concluding remarks: overall impacts on biodiversity and future perspectives for conservation in the Pantanal biome. Brazilian Journal of Biology, vol. 71, no. 1, supplement 1, p. 337-341. PMid:21537607.

ALQUINI, Y., BONA, C., BOEGER, MRT., COSTA, CG. and BARROS, CF., 2003. Epiderme. In: APEZZATO-DA-GLÓRIA, B., CARMELLO-GUERREIRO, SM., Anatomia Vegetal. 2nd ed. Viçosa: UFV. p. 1-438.

ASCENSÃO, L., MOTA, L. and CASTRO, MM., 1999. Glandular Trichomes on the Leaves and Flowers of Plectranthus ornatus: Morphology, Distribution and Histochemistry. Annals of Botany, vol. 84, no. 4, p. 437-447. http://dx.doi.org/10.1006/anbo.1999.0937

CROW, E., STIRTON, CH. and CUTLER, DF., 1997. Leaf anatomy of the genus Psoralea sensu stricto (Psoraleeae, Papilionoideae, Leguminosae). Botanical Journal of the Linnean Society, vol. 124 , no. 4 , p. $155-182$.

DICKISON, WC., 1975. The bases of angiosperm phylogeny: vegetative anatomy. Annals of Missouri Botanical Garden, vol. 62, no. 3, p. 590-620. http://dx.doi.org/10.2307/2395268

ESAU, K., 1985. Anatomia Vegetal. Trad. Dr. José Pons Rossel. Barcelona: Ediciones Omega.

FAHN, A., 1979. Secretory tissues in plants. London: Academic Press.

FAHN, A. and CUTLER, DF., 1992. Xerophytes. Berlin: Gebrüder Borntraeger.

FERNANDES, A., 1996. O Táxon Aeschynomene no Brasil. Fortaleza: EUFC. 130 p.

GOMES, SM., SOMAVILLA, NSDN., GOMES-BEZERRA, KM., MIRANDA, SC., DE-CARVALHO, OS. and GRACIANO-RIBEIRO, D., 2009. Anatomia foliar de espécies de Myrtaceae: contribuições à taxonomia e filogenia. Acta Botanica Brasilica, vol. 23, no. 1, 223-238. http://dx.doi.org/10.1590/S0102-33062009000100024

HEINRICH, G., 1973. Die Feinstruktur der Trichom-Hydathoden vonMonarda fistulosa. Protoplasma, vol. 77, no. 2, p. 271-278. http://dx.doi.org/10.1007/BF01276763

HENEIDAK, S. and SHAHEEN, ASM., 2007. Characteristics of the proximal to distal regions of the petioles to identify 15 tree species of Papilionoideae-Fabaceae. Bangladesh Journal of Plant Taxonomy, vol. 14, no. 2, p. 101-115. http://dx.doi.org/10.3329/ bjpt.v14i2.530

JESUS JUNIOR, LA, OLIVEIRA, RP, LEITE, KRB. and SILVA, LB., 2012. Comparative analysis of the leaf anatomy in two Parodiolyra species (Poaceae: Olyreae) occurring on forests in Eastern Brazil. Brazilian Journal of Biology, vol. 72, no. 1, p. 205-210. PMid:22437403. http://dx.doi.org/10.1590/S151969842012000100025

JOHANSEN, DA., 1940. Plant microtechnique. New York: McGraw-Hill Book Co. Inc. 
KRAUS, JE. and ARDUIN, M., 1997. Manual Básico de Métodos em Morfologia Vegetal. Seropédica: EDUR. 198 p. vol. 1.

LACKEY, JA., 1978. Leaflet Anatomy of Phaseoleae (LeguminosaePapilionoideae) and its relation to Taxonomy. Botanical Gazette, vol. 139 , no. 4 , p. 346-446.

LANGERON, M., 1949. Précis de microscopie. Paris: Masson et Cie. Editers.

LAVIN, M., PENNINGTON, RT., KLITGAARD, BB., SPRENT, JI., DE LIMA, HC. and GASSON, PE., 2001. The dalbergioid legumes (Fabaceae): Delimitation of a pantropical monophyletic clade. American Journal of Botany, vol. 88, no. 3, p. 503-533. PMid:11250829. http://dx.doi.org/10.2307/2657116

LERSTEN, NR. and CURTIS, JD., 1985. Distribution and anatomy of hydathodes in Asteraceae. Botanical Gazette, vol. 146, no. 1, p. 106-114. http://dx.doi.org/10.1086/337504

LIMA, LCP., SARTORI, ALB. and POTT, VJ., 2006. Aeschynomene L. (Leguminosae, Papilionoideae, Aeschynomeneae) no Estado de Mato Grosso do Sul, Brasil. Hoehnea, vol. 33, no. 4, p. 419- 453.

LUSA, MG. and BONA, C., 2009. Análise morfoanatômica comparativa da folha de Bauhinia forficata Link e B. variegata Linn. (Leguminosae, Caesalpinioideae). Acta Botanica Brasilica, vol. 23, no. 1, p. 196-211. http://dx.doi.org/10.1590/S010233062009000100022

Marquiafável, FS., FERREIRA, MDS. and TEIXEIRA, SP., 2009. Novel reports of glands in Neotropical species of Indigofera L. (Leguminosae, Papilionoideae). Flora, vol. 204, no. 3, p. 189-197. http://dx.doi.org/10.1016/j.flora.2008.01.012

METCALFE, CR. and CHALK, L., 1950. Anatomy of the dicotyledons. Oxford: Clarendon Press.

-, 1979. Anatomy of the Dicotyledons. 2 nd ed. Oxford: Clarendon Press. vol. 1.

-, 1985. Anatomy of the dicolydedons. Wood structure and conclusion of the general introduction. 2nd ed. Oxford: Clarendon Press. vol. 2.

POLHILL, RM. and RAVEN, PH., 1978. Advances in legume Systematics. Part 1. Kew: Royal Botanical Gardens.

POTT, A. and POTT, VJ., 1994. Plantas do Pantanal. Brasília: Embrapa.

-, 2000. Plantas Aquáticas do Pantanal. Brasília: Embrapa.

RIBEIRO, RA., LAVIN, M., LEMOS, JP., MENDONCA, CV., SANTOS, FR. and LOVATO, MB., 2007. The genus Machaerium (Leguminosae) is more closely related to Aeschynomene Sect. Ochopodium than to Dalbergia: Inferences from combined sequence data. Systematic Botany, vol. 32, no. 4, p. 762-771. http://dx.doi.org/10.1600/036364407783390700

SARTORI, ALB. and TOZZI, AMGA., 2002. Comparative leaflet anatomy in Myrocarpus Allemão, Myroxylon L. f and Myrospermum Jacq. (Leguminosae-Papilionoideae-Sophoreae) species. Botanical Journal of the Linnean Society, vol. 140, no. 3, p. 249-259. http:// dx.doi.org/10.1046/j.1095-8339.2002.t01-1-00088.x

SCREMIN-DIAS, E., 1999. O retorno à origem aquática. In SCREMIN-DIAS, E., POTT, VJ., HORA, RC. and SOUZA, PR. Nos jardins submersos da Bodoquena. Campo Grande: Editora UFMS.

-, 2009. Tropical aquatic plants: morphoanatomical adaptations. In DEL-CLARO, K. and RICO-GRAY (Org.). Encyclopedia of Tropical Biology and Conservation Management. Paris: UNESCO/ EOLSS. p. 84-132. vol. 1. Available from: <http:www.eolss.net>.

SCREMIN-DIAS, E., LORENZ-LEMKE, AP. and OLIVEIRA, AK., 2011. The floristic heterogeneity of the Pantanal and the occurrence of species with different adaptive strategies to water stress. Brazilian Journal of Biology, vol. 71, no. 1, Suppl 1, p. 275-282. PMid:21537600. http://dx.doi.org/10.1590/S151969842011000200006

SCULTHORPE, CD., 1967. The Biology of Aquatic Vascular Plants. New York: St. Martin's Press.

SILVA, LM, ALQUINI, Y. and CAVALLET, VJ., 2005. Interrelações entre a anatomia vegetal e a produção vegetal. Acta Botanica Brasilica, vol. 19, no. 1, p. 183-194. http://dx.doi. org/10.1590/S0102-33062005000100018

SOLEREDER, H., 1908. Systematic anatomy of the dicotyledons. 2nd ed. Oxford: Clarendon Press. 2 vol.

TEIXEIRA, SP. and GABRIELLI, AC., 2006. Taxonomic value of foliar characters in Dahlstedtia Malme - Leguminosae, Papilionoideae, Millettieae. Acta Botanica Brasilica, vol. 20, no. 2, p. 395-403. http://dx.doi.org/10.1590/S0102-33062006000200014

WILKINSON, HP., 1979. The plant surface (mainly leaf). In METCALFE, CR. and CHALK, L. (Eds.). Anatomy of the Dicotyledons: systematic anatomy of the leaf and stem. Oxford: Claredon Press. p. 97-165.

WINK, M., 2003. Evolution of secondary metabolites from an ecological and molecular phylogenetic perspective. Review. Phytochemistry, vol. 64, no. 1, p. 3-19. http://dx.doi.org/10.1016/ S0031-9422(03)00300-5

ZORIC, L., MERKULOV, L., LUKOVIC, J. and BOZA, P., 2012. Comparative analysis of qualitative anatomical characters of Trifolium L. (Fabaceae) and their taxonomic implications: preliminary results. Plant Systematics and Evolution, vol. 298, no. 1, p. 205-219. http://dx.doi.org/10.1007/s00606-011-0538-8 